\title{
A commented list of Scaphopoda (Mollusca) found along the Brazilian coast, with two new synonymies in the genus Gadila Gray, 1847
}

\author{
Leonardo Santos de Souza ${ }^{1,2}$, Isabella Campos Vieira Araújo ${ }^{I}$ \& Carlos Henrique Soares Caetano \\ ${ }^{1}$ Departamento de Zoologia, Instituto de Biociências, Universidade Federal do Estado do Rio de \\ Janeiro - UNIRIO, Av. Pasteur, 458, Urca, CEP 22290-240, Rio de Janeiro, RJ, Brasil \\ ${ }^{2}$ Corresponding author: Leonardo Santos de Souza, e-mail: leosouza2301@gmail.com
}

SOUZA, L.S., ARAÚJO, I.C.V. \& CAETANO, C.H.S. A commented list of Scaphopoda (Mollusca) found along the Brazilian coast, with two new synonymies in the genus Gadila Gray, 1847. Biota Neotrop. (13)2: http://www.biotaneotropica.org.br/v13n2/en/abstract?inventory+bn03213022013

Abstract: This review aims to present an updated checklist of scaphopods, based mainly on literature database. There is a total of 40 species (six families) for Brazil, including information about the distribution and bathymetric range of each taxon. We propose two synonyms with the aid of morphometry of the shell, for the genus Gadila: $G$. longa as junior synonym of $G$. elongata and G. robusta as junior synonym of G. pandionis.

Keywords: scaphopods, morphometry, synonyms, distribution, bathymetry.

SOUZA, L.S., ARAÚJO, I.C.V. \& CAETANO, C.H.S. Lista comentada dos Scaphopoda (Mollusca) encontrados ao longo da costa Brasileira, com duas novas sinonímias no gênero Gadila Gray, 1847. Biota Neotrop. 13(2): http://www.biotaneotropica.org.br/v13n2/pt/abstract?inventory+bn0321302201

Resumo: Uma lista atualizada dos escafópodes da costa brasileira pertencentes a seis famílias é apresentada baseada principalmente em dados da literatura. Há um total de 40 espécies para o Brasil, incluindo informações sobre a distribuição e a faixa batimétrica de cada táxon. Nós propomos dois sinônimos com o auxílio da morfometria da concha, para o gênero Gadila: G. longa como sinônimo júnior de G. elongata e G. robusta como sinônimo júnior de G. pandionis.

Palavras-chave: escafópodes, morfometria, sinônimos, distribuição, batimetria. 


\section{Introduction}

Scaphopods are infaunal marine burrowers that can be found in oceans all over the world, either in intertidal zones or in abyssal depths (Reynolds \& Steiner 2008). They are distinguished by an external tubular shell, opened at both ends and with a degree of curvature (Reynolds 2002).

The group currently comprises 565 valid species (Steiner \& Kabat 2004, Caetano \& Absalão 2005, Caetano et al. 2006, Scarabino 2008, Scarabino \& Caetano 2008, Gracia \& Ardila 2009, Simone 2009, Scarabino \& Scarabino 2010) and had its classification recently discussed by Steiner $(1992,1998,1999)$ and Scarabino (1995). Two orders were recognized at the end: Dentaliida and Gadilida. The first species reported in Brazil were described by Watson (1879): Siphonodentalium tetraschistus, found in Fernando de Noronha Island and Dentalium circumcinctum, in the state of Pernambuco. Henderson (1920) led the first monographic work that dealt with Western Atlantic Scaphopoda. The review studied 110 species, 11 of which were identified in Brazil.

Amaral \& Jablonsky (2005) included Scaphopoda within the main groups of invertebrates in terms of abundance or frequence of brazilian benthos, but Caetano \& Santos (2010) claimed that this biodiversity had been underestimated, since aspects of taxonomy and biology of scaphopods from brazilian waters had not been well-studied (Penna 1972, Penna-Neme 1974, Caetano \& Absalão 2005, Caetano et al. 2006, 2010, Massud-Ribeiro \& Caetano 2006, Scarabino \& Caetano 2008).

Recently, oceanographic campaigns have increased the knowledge of deep-water species. Therefore, the aim of this work is to update the biodiversity of scaphopods from Brazilian coast, presenting their geographic distribution and bathymetric ranges. Synonymies are also being proposed, with the aid of morphometric tools.

\section{Material and Methods}

The research on Brazilian Scaphopoda involved academic databases (ISI Web of Knowledge, Malacolog 4.1.1, WoRMS - World Register of Marine Species and Google Scholar) and other scientific publications concerning the species. New data (unpublished records) from Campos Basin, Rio de Janeiro, Brazil, were also included.

Considered synonymous, Gadila longa and G. robusta (SilvaFilho et al. 2010) were examined through photos of the types (SilvaFilho et al. 2010) and paratypes deposited at Museu Nacional da Universidade Federal do Rio de Janeiro (MNRJ). Comparisons of several species of Gadila were carried out from empty shells, photos of the types and original descriptions.

Furthermore, morphometric variables were used, according to Caetano et al. (2010), as tools for the comparison of the species. Only undamaged shells were taken into consideration and each specimen was drawn by means of a camera lucida. The following variables were applied: (L) Length, (Max) maximum diameter, (Dmax) distance of point of maximum diameter from anterior aperture, (Arc) maximum curvature, (Larc) distance of point of maximum curvature from the Apex, (Ha) anterior aperture height, (Wa) anterior aperture width, $(\mathrm{Hp})$ apical aperture height and $(\mathrm{Wp})$ apical aperture width.

List of abbreviations of the malacological collections: IBUFRJ - Instituto de Biologia, Universidade Federal do Rio de Janeiro, Brazil; MNRJ - Museu Nacional do Rio de Janeiro, Universidade Federal do Rio de Janeiro, Brazil; MORG - Museu Oceanográfico do Rio Grande, Brazil; USNM - National Museum of Natural History, Smithsonian Institution, USA; BMNH - National Hystory Museum, London, England.

\section{Results}

Forty species of Scaphopoda were recorded in Brazil. From 18 species of Dentaliida: 14 species (six genera) belonged to Dentaliidae, two species (one genus) to Fustiariidae and the last two species (one genus) belonged to Gadilinidae. From 22 species of Gadilida: three species (three genera) belonged to Entalinidae, two species (two genera) to Pulsellidae and 17 species (five genera) belonged to Gadilidae. We found five endemic species: Heteroschismoides meridionalis Scarabino \& Scarabino (2008), Striopulsellum atlantis Scarabino \& Scarabino (2011), Polyschides noronhensis Simone (2009), Cadulus eliezeri Caetano, Scarabino \& Absalão (2006) and C. nerta Caetano, Scarabino \& Absalão (2006). Two species had amphi-atlantic distribution, Fissidentalium candidum (Jeffreys, 1877) and Gadila cretea Scarabino \& Scarabino (2011). Regarding the bathymetric distribution, species were found from infralittoral areas to $4850 \mathrm{~m}$ depths.

The species identified in Brazilian waters are listed below in a systematic order. The distribution, bibliography and bathymetric range were taken into consideration.

Order DENTALIIDA da Costa, 1778

Family Dentaliidae Gray, 1847

Genus Dentalium Linnaeus, 1758

Dentalium laqueatum Verrill, 1885

Distribution: USA -North Carolina, Florida, Georgia; Gulf of Mexico- (Camp et al. 1998, Wolfe 2008); Caribe -, Cuba, Puerto Rico, Jamaica, Antigua, Barbados and Grenada, Yucatan, Campeche bank- (Henderson 1920, Raffucci 2007); Colombia (Gracia et al. 2005); Brazil -Amapá to Santa Catarina- (Penna-Neme 1974, Scarabino 1994). Specimens with soft parts collected between 82 (Caetano et al. 2006) and $225 \mathrm{~m}$ depths (Sander \& Lalli 1982); empty shells between 30 (Wolfe 2008) and $900 \mathrm{~m}$ depths (Gracia et al. 2005).

Genus Paradentalium Cotton \& Godfrey, 1933

Paradentalium disparile (Orbigny, 1853)

Distribution: USA -Florida-; Puerto Rico (Raffucci 2007); Antilles; Cuba; Trinidad (Henderson 1920, Turner 1955); Colombia (García-Valencia \& Díaz 2000); Brazil -Amapá to Santa Catarina(Henderson 1920, Penna-Neme 1974, Scarabino 1994, Caetano et al. 2006, Caregnato et al. 2009). Specimens with soft parts collected between 5 and $50 \mathrm{~m}$ depths, empty shells since intertidal zone to 103 $m$ depths (Caetano et al. 2006).

Paradentalium gouldii (Dall, 1889)

Distribution: USA - North Carolina, South Carolina- (Dall 1889, Rosenberg 2009); Puerto Rico (Henderson 1920); Suriname; Colombia (Gracia et al. 2005); Brazil -Amapá, Maranhão, Alagoas, Sergipe, Bahia to São Paulo, Santa Catarina, Rio Grande do Sul(Absalão 1989, Scarabino 1994, Caetano et al. 2006). Empty shells between 20 and $1050 \mathrm{~m}$ depths (Gracia et al. 2005, Caetano \& Scarabino 2009).

Paradentalium infractum (Odhner, 1931)

Distribution: Venezuela (Caetano et al. 2007); Brazil -Amapá, Maranhão, Alagoas, Bahia, Espírito Santo, Rio de Janeiro, São Paulo, Santa Catarina and Rio Grande do Sul- (Caetano et al. 2006, Penna-Neme 1974, Scarabino 1973, 1994); Uruguay (Scarabino 1973, 2003); Argentina. Specimens with soft parts collected between 40 and $190 \mathrm{~m}$ depths, empty shells between 5 and $269 \mathrm{~m}$ depths (Caetano et al. 2006).

Genus Antalis H. \& A. Adams, 1854

Antalis cerata (Dall, 1881)

Distribution: USA-Florida, "Florida Keys", mouth of Mississippi River, Alabama-; Cuba: Havana, Martinica and Barbados; Yucatan; Puerto Rico (Raffucci 2007): Mayaguez; Barbados (Henderson 1920, Sander \& Lalli 1982); Brazil -Amapá to Rio Grande do Sul- 
(Penna-Neme 1974, Scarabino 1975, 1994); Uruguay -Rio de la Plata- (Scarabino 1973, 2003). Specimens with soft parts collected between 32 and $338 \mathrm{~m}$ depths, empty shells up to $1960 \mathrm{~m}$ depths (Penna-Neme 1974, Steiner \& Kabat 2004).

Antalis circumcincta (Watson, 1879)

Distribution: Puerto Rico (Raffucci 2007) Bermuda (Abbott 1974); Antilles -St. Thomas-; Brazil -Pernambuco, Bahia, Espírito Santo and São Paulo- (Caetano et al. 2006, Sumida \& Pires-Vanin 1997). Exemplars with soft parts collected between 700 and 1000 $m$ depths (Campos Basin, this study, MNRJ 16498-16500), empty shells between 247 and 1962 m depths (Steiner \& Kabat 2004, Caetano et al. 2006).

Antalis pilsbryi (Rehder, 1942)

Distribution: USA -Florida- (Camp et al. 1998); Brazil -São Paulo- (Henderson 1920, Scarabino 1975, 1994). Empty shells between 0 and $15 \mathrm{~m}$ depths (Steiner \& Kabat 2004).

Antalis taphria (Dall, 1889)

Distribution: USA-North Carolina, Florida, Georgia-(Henderson 1920, Camp et al. 1998, Wolfe 2008); Cuba-Havana-; Puerto Rico (Raffucci 2007); Yucatan (Turner 1955); Brazil -Fernando de Noronha, Atol das Rocas, Amapá to Rio de Janeiro- (Scarabino 1975, 1994, Caetano et al. 2006). Specimens with soft parts collected between 41 and $90 \mathrm{~m}$ depths; empty shells between 15 and $692 \mathrm{~m}$ depths (Steiner \& Kabat 2004).

Genus Graptacme Pilsbry \& Sharp, 1897

Graptacme calamus (Dall, 1889)

Distribution: USA -North Carolina, Florida, Georgia- (Abbott 1974, Camp et al. 1998, Wolfe 2008); Cuba; Puerto Rico (Raffucci 2007); Brazil -Amapá to Rio Grande do Sul- (Penna-Neme 1974, Scarabino 1975, 1994); Uruguay (Scarabino 2003). Specimens with soft parts collected between 17 and $124 \mathrm{~m}$ depths, empty shells from intertidal zone to $124 \mathrm{~m}$ depths (Steiner \& Kabat 2004).

Graptacme eborea (Conrad, 1846)

Distribution: USA-North Carolina, Florida, Georgia-(Henderson 1920, Camp et al. 1998, Wolfe 2008); Santo Domingo; Puerto Rico (Raffucci 2007); Antigua; Yucatan; Venezuela (Buitrago et al. 2006); Brazil -Pará, Maranhão, Rio Grande do Norte, Espírito Santo, Rio de Janeiro, Abrolhos, Fernando de Noronha and Atol das Rocas(Scarabino 1975, 1994, Rios \& Barcellos 1980, Caetano et al. 2006). Specimens with soft parts collected between 16 and $95 \mathrm{~m}$ depths (Lewis 1965); empty shells between 5 and $195 \mathrm{~m}$ depths (Caetano \& Scarabino 2009).

Graptacme perlonga (Dall, 1881)

Distribution: USA -North Carolina to Florida-; Gulf of Mexico; Puerto Rico (Raffucci 2007); Grenada; Brazil -Ceará, Bahia and Rio de Janeiro- (Henderson 1920, Caetano et al. 2006). Specimens with soft parts collected between 1000 and $1600 \mathrm{~m}$ depths; empty shells between 200 and $4850 \mathrm{~m}$ depths (Caetano et al. 2006, Steiner \& Kabat 2004).

Graptacme semistriolata (Guilding, 1834)

Distribution: USA -Florida- (Camp et al. 1998); Bermuda; St. Martin; Cuba; Bahamas (Redfern 2001); Virgin Islands (Turner 1955 , Raffucci 2007); Mexico (Baker 1891); French Guiana; Brazil-Amapá to São Paulo-(Penna-Neme 1974, Scarabino 1975, 1994). Specimens with soft parts collected between 20 and $75 \mathrm{~m}$ depths, empty shells between 15 and 150 m depths (Penna-Neme 1974, Scarabino 1994).

Genus Fissidentalium Fischer, 1885

Fissidentalium candidum (Jeffreys, 1877)

Distribution: Presents amphi-Atlantic distribution, Greenland to Brazil -Rio de Janeiro- on Western Atlantic (Pilsbry \& Sharp 1897, Steiner \& Kabat 2004) and Greenland to Africa-Namibia- on Eastern Atlantic (Steiner \& Kabat 2004). Specimens with soft parts collected between 1000 and 1600 m depths (Campos Basin - Rio de Janeiro, this study, MNRJ 16503); Specimens collected under unknown biological condition between 403 and $3814 \mathrm{~m}$ depths (Steiner \& Kabat 2004).

Genus Coccodentalium Sacco, 1896

Coccodentalium carduus (Dall, 1889)

Distribution: USA -North Carolina, Florida- (Henderson 1920, Abbott 1974); Barbados; Brazil -Alagoas to Rio Grande do Sul(Penna-Neme 1974, Scarabino 1975, 1994). Specimens with soft parts collected between 180 and 247 m depths (Penna-Neme 1974, Caetano et al. 2006); empty shells between 40 and $1980 \mathrm{~m}$ depths (Steiner \& Kabat 2004, Caetano et al. 2006).

Family Fustiariidae Steiner, 1991

Genus Fustiaria Stoliczka, 1868

Fustiaria liodon (Pilsbry \& Sharp, 1897)

Distribution: USA -Florida-; Caribe -St. Martin, Barbados, Puerto Rico, Antigua, Honduras- (Pilsbry \& Sharp 1897, Henderson 1920, Raffucci 2007); Brazil -Amapá to Rio de Janeiro, including Fernando de Noronha- (Penna-Neme 1974, Scarabino 1975, 1994, Cabral \& Mello 1994). Specimens with soft parts collected between 26 and $59 \mathrm{~m}$ depths, empty shells between intertidal zone and $150 \mathrm{~m}$ depths (Penna-Neme 1974, Caetano et al. 2006).

Fustiaria stenoschiza (Pilsbry \& Sharp, 1897)

Distribution: USA -Florida- (Abbott 1974); Antilles (Pilsbry \& Sharp 1897); Puerto Rico (Raffucci 2007); Barbados; Brazil-Espírito Santo- (Caetano et al. 2006). Specimens with soft parts collected at $96 \mathrm{~m}$, empty shells between 40 and $120 \mathrm{~m}$ (Caetano et al. 2006).

Family Gadilinidae Chistikov, 1975

Genus Episiphon Pilsbry \& Sharp, 1897

Episiphon didymum (Watson, 1879)

Distribution: Caribe -"South Dry Tortugas", Bahamas, Puerto Rico, Barbados; "St. Thomas", Virgin Islands, Culebra Islands(Turner 1955, Henderson 1920, Emerson 1952, Caetano et al. 2006, Raffucci 2007); Colombia (Díaz \& Puyana 1994); Brazil -Amapá, Maranhão, Alagoas, Bahia, Espírito Santo, Rio de Janeiro, Rio Grande do Sul- (Penna-Neme 1974, Scarabino 1994, Caetano et al. 2006). Specimens with soft parts collected between 100 (Campos Basin, this study, MNRJ 16490) and 439 m depths; empty shells between 60 and $830 \mathrm{~m}$ depths (Emerson 1952).

Episiphon sowerbyi (Guilding, 1834)

Distribution: USA -North Carolina, Florida- (Henderson 1920, Turner 1955, Camp et al. 1998); Gulf of Mexico; Cuba; Puerto Rico (Raffucci 2007); Barbados (Henderson 1920, Lewis 1965); Brazil -Amapá, Maranhão, Alagoas, Bahia, Rio de Janeiro, São Paulo(Scarabino 1994, Caetano et al. 2006). Specimens with soft parts collected between 13 and $200 \mathrm{~m}$ depths; empty shells up to $830 \mathrm{~m}$ depths (Caetano et al. 2006).

\section{Order GADILIDA Starobogatov, 1974}

Suborder Entalimorpha Steiner, 1992

Family Entalinidae Chistikov, 1979

Genus Entalina Monterosato, 1872

Entalina platamodes (Watson, 1879)

Distribution: USA -Florida, Georgia- (Abbott 1974, Rosenberg 2009); Cuba; Colombia (Gracia et al. 2005); Puerto Rico (Emerson 1952, Raffucci 2007); Culebra Islands (Caetano et al. 2006); Brazil -Alagoas, Bahia and Rio de Janeiro-(Penna-Neme 1974, Scarabino 1994, Caetano et al. 2006). Specimens with soft parts collected between 290 (Penna-Neme 1974) and $400 \mathrm{~m}$ depths (Campos Basin, this study, MNRJ 16485-16488), empty shells between 20 (Caetano et al. 2006) and $1400 \mathrm{~m}$ depths (Gracia et al. 2005).

Genus Pertusiconcha Chistikov, 1982

Pertusiconcha callithrix (Dall, 1889)

Distribution: USA -North Carolina-; Yucatan; Puerto Rico (Raffucci 2007); Guadalupe; Grenada; Trinidad and Tobago; Brazil 
-Rio de Janeiro and São Paulo- (Henderson 1920). Specimens with soft parts collected up to $2320 \mathrm{~m}$ depths, empty shells between 402 and $3500 \mathrm{~m}$ depths (Caetano et al. 2006).

Subfamily Heteroschismoidinae Chistikov, 1982

Genus Heteroschismoides Ludbrook, 1960

Heteroschismoides meridionalis Scarabino \& Caetano, 2008

Distribution: Brazil -Espírito Santo and São Paulo-. Specimens with soft parts collected at $1540 \mathrm{~m}$ depths, empty shells between 790 and $1540 \mathrm{~m}$ depths (Scarabino \& Caetano 2008).

Suborder Gadilimorpha Steiner, 1992

Family Pulsellidae Scarabino in Boss, 1982

Genus Annulipulsellum Scarabino, 1986

Annulipulsellum euzkadii Scarabino, 1986

Distribuição: North Atlantic -particularly Gulf of Gasconha-; Puerto Rico; Brazil -Pernambuco- (Scarabino 1986). Specimens with soft parts collected between 1407 and $4225 \mathrm{~m}$ depths (Scarabino 1986, Steiner \& Kabat 2004).

Genus Striopulsellum Scarabino, 1995

Striopulsellum atlantis Scarabino \& Scarabino, 2011

Distribution: Brazil -Pernambuco-. Specimens with soft parts collected between 907 and $1007 \mathrm{~m}$ depths (Scarabino \& Scarabino 2011).

Family Gadilidae Stoliczka, 1868

Genus Polyschides Pilsbry \& Sharp, 1898

Polyschides noronhensis Simone, 2009

Distribution: Brazil -Fernando de Noronha-. Specimens with soft parts collected at $6 \mathrm{~m}$ depths (Simone 2009).

Polyschides portoricensis (Henderson, 1920)

Distribution: Puerto Rico (Henderson 1920, Raffucci 2007); Colombia (Díaz \& Puyana 1994); Brazil -Amapá, Pará, Alagoas, Bahia and Rio de Janeiro- (Caetano \& Absalão 2005). Empty shells between intertidal zone and $120 \mathrm{~m}$ depths (Steiner \& Kabat 2004, Caetano \& Absalão 2005).

Polyschides tetraschistus (Watson, 1879)

Distribution: USA -North Carolina, Georgia- (Abbott 1974, Wolfe 2008); Bermudas; Cuba (Turner 1955); between Margarida Island and the Peninsula of Araya; Bahamas (Caetano et al. 2006); Colombia (Díaz \& Puyana 1994); Brazil -Amapá to Rio Grande do Sul, Fernando de Noronha and Abrolhos- (Penna-Neme 1974, Scarabino 1975, 1994, Caetano \& Absalão 2005, Caetano et al. 2006); Uruguay -Rio de la Plata-(Turner 1955, Scarabino 2003); Argentina -Buenos Aires, Quequen Port, Gulf of São Matias- (Turner 1955, Scarabino 1973). Specimens with soft parts collected from low tide to $71 \mathrm{~m}$ depths, empty shells since intertidal zone to $120 \mathrm{~m}$ depths (Caetano \& Absalão 2005, Caetano \& Scarabino 2009).

Polyschides xavante Caetano \& Absalão, 2005

Distribution: Colombia; Brazil -Fernando de Noronha, Pernambuco-. Empty shells between 10 and $15 \mathrm{~m}$ depths (Caetano \& Absalão 2005).

Genus Cadulus Philippi, 1844

Cadulus eliezeri Caetano, Scarabino \& Absalão, 2006

Distribution: Brazil -Amapá, Bahia to Rio de Janeiro-. Empty shells between 46 and $230 \mathrm{~m}$ depths (Caetano et al. 2006).

Cadulus nerta Caetano, Scarabino \& Absalão, 2006

Distribution: Brazil -Espírito Santo-- Empty shells find on 247 $\mathrm{m}$ depths (Caetano et al. 2006).

Cadulus parvus Henderson, 1920

Distribution: USA -Florida-; Barbados; cape San Antonio; Yucatan (Henderson 1920); Colombia (Díaz \& Puyana 1994); Brazil -Cape Orange, mouth of Amazonas River, Bahia to São Paulo(Scarabino 1994, Absalão 1989, Caetano et al. 2006). Specimens with soft parts collected at $50 \mathrm{~m}$ depths (Campos Basin, this study,
MNRJ 16495-16496), empty shells between 50 and $220 \mathrm{~m}$ depths, and an uncertain record for $1837 \mathrm{~m}$ depths (Caetano et al. 2006).

Cadulus platensis Henderson, 1920

Distribution: USA-Georgia, Florida-(Henderson 1920); Brazil -Ceará, Santos - São Paulo- (Henderson 1920, Scarabino 1994); Argentina-Rio de la Plata-(Henderson 1920). Empty shells collected between 538 and $3059 \mathrm{~m}$ depths (Henderson 1920, Scarabino 1994).

Genus Gadila Gray, 1847

Gadila braziliensis (Henderson, 1920)

Distribution: Brazil -Rio de Janeiro, São Paulo, Rio Grande do Sul-; Uruguay; Argentina-Rio de la Plata- (Turner 1955, Scarabino 1973, 1994, 2003). Specimens with soft parts collected between 50 and $100 \mathrm{~m}$ depths (Campos Basin, this study, MNRJ 16491-16492), empty shells between 23 and 220 m depths (Steiner \& Kabat 2004).

Gadila cretea Scarabino \& Sarabino, 2011

Distribution: Amphi-Atlantic distribution. Western Atlantic: Puerto Rico -Puerto Rico Trench- and Brazil -Pernambuco on Fernando de Noronha-- Eastern Atlantic: Gulf of Gasconha to Azores. Specimens with soft parts collected between 3264 and $4510 \mathrm{~m}$ depths (Scarabino \& Scarabino 2011).

Gadila dominguensis (Orbigny, 1853)

Distribution: USA -Florida- (Abbott 1974); Puerto Rico (Emerson 1952, Raffucci 2007); Honduras; Guatemala; Belize (Henderson 1920); Cuba; St. Thomas; Martinique; Dominican Republic (Emerson 1952); Colombia (Díaz \& Puyana 1994); Suriname (Caetano et al. 2006); Brazil -Amapá to Rio de Janeiro(Scarabino 1994, Caetano et al. 2006). Specimens with soft parts collected between 53 and 103 m depths (Penna-Neme 1974); empty shells since seashore to $100 \mathrm{~m}$ depths (Caetano et al. 2006, Caetano \& Scarabino 2009).

Gadila elongata (Henderson, 1920). Figure 1 [1-3].

Cadulus (Platyschides) elongatus Henderson, 1920: 122, pl. 19, Figure 15.

Polyschides elongates: Steiner \& Kabat, 2004: 587.

Gadila elongata: Caetano et al., 2010: 306, Figure 1-3.

Gadila longa Silva-Filho, Pinto \& Alves 2010: 50, Figure 2. Syn. nov.

Diagnosis, type material, type locality: see Caetano et al. (2010)

Distribution: USA - mouth of Mississipi River-; Brazil - Ceará, Rio Grande do Norte -. Empty shells between 124 and $177 \mathrm{~m}$ depths (Henderson 1920, Steiner \& Kabat 2004, Caetano et al. 2010, SilvaFilho et al. 2010).

Material examined: Paratype of Gadila longa (MNRJ 10482), G. elongata (MNRJ 31141)

Remarks: The shell presented by Silva-Filho et al. (2010) have the same features of G. elongata (holotype showed at Figure 1), both were regularly curved, very slender, with the maximum diameter placed in the anterior fifth of the shell. The shells were smooth and opaque white. They also had circular and slightly flat apex, and oblique apertures.

In his study, Caetano et al. (2010) depicted a shell that was wrongly labelled as MNRJ 10482. This specimen (Figure 1 [2,3]) was collected off Ceará (same locality of paratype of G. longa - Figure 1 [4] - but not belong to the type series), being included in an additional lot (MNRJ 31141).

The morphometric data obtained from the type material of G. longa and G. elongata (Table 1) were different in general, but it may be caused by the difference in length. The material from Northeast Brazil presented lower values than holotype of G. elongata. The most similar dimensions were the maximum diameter (Max) and anterior aperture width (Wa). The type material of $G$. longa was possibly constituted of young specimens. The paratype of $G$. longa 
Table 1. Values of shell morphometric parameters for species of Gadila studied. (L) Length, (Max) maximum diameter, (Dmax) distance of point of maximum diameter from anterior aperture, (Arc) maximum curvature, (Larc) distance of point of maximum curvature from the Apex, (Ha) anterior aperture height, (Wa) anterior aperture width, (Hp) apical aperture height, (Wp) apical aperture width, (SD) standard deviation. All measurements are in milimeters. *Type dimensions obtained from holotypes (Silva-Filho et al., 2010) and paratypes (MNRJ 10482 and MNRJ 10483, respectively: measured in this study). **Type dimensions obtained from Henderson (1920). ***Values obtained from IBUFRJ 10698 and IBUFRJ 14313.

\begin{tabular}{|c|c|c|c|c|c|c|}
\hline & \multirow{2}{*}{$\begin{array}{c}\text { G. } \operatorname{longa}(\mathrm{n}=2)^{*} \\
\min -\max \end{array}$} & \multirow{2}{*}{$\begin{array}{c}\text { G. elongata }{ }^{* *} \\
\text { Holotype }\end{array}$} & \multirow{2}{*}{$\begin{array}{c}\text { G. robusta }(\mathrm{n}=2)^{*} \\
\min -\max \end{array}$} & \multirow{2}{*}{$\begin{array}{c}\text { G. pandionis }{ }^{* *} \\
\text { Holotype }\end{array}$} & \multicolumn{2}{|c|}{ G. pandionis $(\mathrm{n}=18) * * *$} \\
\hline & & & & & mean $( \pm$ SD) & min-max \\
\hline $\bar{L}$ & $7.9-11.0$ & 14.1 & $5.9-8.0$ & 10.0 & $10.8(2.3)$ & $6.3-13.7$ \\
\hline Max & $1.3-2.0$ & 1.5 & $1.2-2.0$ & 2.0 & $1.7(0.4)$ & $0.9-2.5$ \\
\hline Dmax & $1.3-1.8$ & & $1.2-2.0$ & & $3.8(0.9)$ & $2.3-4.8$ \\
\hline Arc & $0.4-2.0$ & & $0.4-3.0$ & & $0.9(0.2)$ & $0.5-1.3$ \\
\hline Larc & $3.0-3.3$ & & $2.4-4.0$ & & $4.3(0.1)$ & $2.4-5.9$ \\
\hline $\mathrm{Ha}$ & $0.5-0.5$ & 1.4 & $0.4-0.4$ & & $1.0(0.2)$ & $0.7-1.2$ \\
\hline $\mathrm{Wa}$ & $0.6-1.2$ & 1.0 & $0.4-1.0$ & 1.75 & $1.2(0.3)$ & $0.7-1.7$ \\
\hline Hp & $1.0-1.0$ & 0.4 & $0.6-0.6$ & & $0.4(0.1)$ & $0.2-0.6$ \\
\hline $\mathrm{Wp}$ & $0.4-1.2$ & 0.4 & $0.5-0.9$ & 0.4 & $0.5(0.1)$ & $0.3-0.7$ \\
\hline
\end{tabular}

was an extremely eroded shell with a broken apex, which resulted in higher Hp and Wp values.

Gadila pandionis (Verril \& Smith in Verril, 1880) (Figure 1 [5-7]).

Cadulus pandionis Verril \& Smith (in Verril), 1880: 392, 399; Verril, 1882: 558, pl. 58, Figures 30, 30a.

Cadulus (Gadila) pandions: Pilsbry \& Sharp, 1898: 171, pl. 25, Figure 63.

Cadulus (Platyschides) pandionis: Henderson, 1920: 118, pl. 18 , Figure 10.

Gadila pandionis: Steiner \& Kabat, 2001: 445; 2004: 626; Caetano et al., 2006: 39, Figures 78-80.

Gadila robusta Silva-Filho, Pinto \& Alves, 2010: 51, Figure 3. Syn. nov.

Diagnosis, type material, type locality: see Caetano et al. (2006).

Distribution: USA -Massachusetts, New Jersey to Florida(Steiner \& Kabat 2004; Rosenberg 2009); Brazil -Rio Grande do Norte, Bahia, Espírito Santo, Rio de Janeiro- (Caetano et al. 2006), Rio Grande do Sul (this study: MORG 25107, MNRJ 4198). Specimens with soft parts collected between 400 and $700 \mathrm{~m}$ depths (Campos Basin, this study, MNRJ 16493-16494), empty shells between 46 and $1320 \mathrm{~m}$ depths (Caetano et al. 2006).

Material examined: Paratype of G. robusta (MNUFRJ 10483); Lectotype of $G$. pandionis (USNM 38644); and IBUFRJ 10698, IBUFRJ 14313, IBUFRJ 14314.

Remarks: both shells were strongly curved and had a bulge at the maximum diameter, which was located at the anterior third of the shell. Gadila pandionis had an apex with two U-shaped notches: a ventral and a dorsal one (Figure 1[5-7]). Paratype of G. robusta showed only the dorsal U-shaped notch at the apex. (Figure 1[8-9]).

The majority of the morphometric variables of the two taxa were either similar or included in the range of $G$. pandionis. Values of Dmax, Ha and Arc presented differences that could be related to shell sizes. The material found in the Northeast of Brazil showed lower values for Dmax and Ha compared to the range of G. pandionis, whose Arc values were higher.

Gadila pocula (Dall, 1889)

Distribution: St. Vincent; Yucatan ; Brazil -Rio de Janeiro-. Empty shells between 774 and 1173 m depths (Henderson 1920, Caetano et al. 2006).

Gadila simpsoni (Henderson, 1920)

Distribution: Antigua -English Harbor; Cuba; Puerto Rico (Henderson 1920, Raffucci 2007); Brazil -Bahia to Rio de Janeiro(Caetano et al. 2006). Empty shells between 46 and $575 \mathrm{~m}$ depths (Steiner \& Kabat 2004).
Genus Striocadulus Emerson, 1962

Striocadulus magdalenensis Gracia \& Ardila, 2009

Distribution: Colombia (Gracia \& Ardila 2009); Brazil -Amapá(Caetano \& Santos 2010). Specimens with soft parts collected between 404 and $412 \mathrm{~m}$ depths, empty shells between 404 and $700 \mathrm{~m}$ depths (Gracia \& Ardila 2009, Caetano \& Santos 2010).

GADILIDA, Incertae sedis

Genus Compressidens Pilsbry \& Sharp, 1897

Compressidens pressum (Pilsbry \& Sharp, 1897)

Distribution: USA -North Carolina on Cape Hatteras, Florida(Henderson 1920, Scarabino 2012); Puerto Rico (Raffucci 2007); Colombia (Gracia et al. 2005); Brazil -Ceará, Recife - Pernambuco, Bahia to Rio de Janeiro-(Cabral \& Mello 1994, Caetano et al. 2006). Specimens with soft parts collected at $400 \mathrm{~m}$ depths (Campos Basin, this study, MNRJ 16501-16502), empty shells between 45 and $1650 \mathrm{~m}$ depths (Caetano et al. 2006, Caetano \& Scarabino 2009).

\section{Species with Doubtful Ocurrence in Brazil}

Four of the species mentioned in the literature were not included in the updated list of Brazilian Scaphopoda because their records presented uncertainties.

Paradentalium americanum (Chenu, 1843)

Some authors have mentioned the shell-wise similarities between $P$. americanum and $P$. gouldii. They have also commented about the possibility of them being synonymous (Henderson 1920, Pilsbry \& Sharp 1897). Furthermore, comparing the holotype of $P$. texasianum rioense (USNM 96114a) (normally included in the synonymy of $P$. americanum) with specimens of $P$. gouldii, we agree with the statements mentioned above. Despite the possibility of synonymy, as we not examined the syntype of $P$. americanum, we preferred to consider both taxa as valid.

All these factors lead to an unestablished concept about $P$. americanum and $P$. gouldii. On the other hand, the exhaustive examination of conchological material from Brazil allows us to affirm that there is only one morphotype, which designated $P$. gouldii, due to the presence of longitudinal ribs in the intercostal space. Therefore, the occurrence of $P$. americanum for brazilian waters was considered doubtful.

Antalis antillaris (Orbigny, 1853)

After a careful review of the shells deposited on the brazilian malacological collections, none of the specimens fitted the concept of $A$. antillaris. Rios \& Oleiro (1968) did the first mention for A. antillaris in Brazil, reporting the species off Rio de Janeiro. The material on which the authors based their record has not been located, 


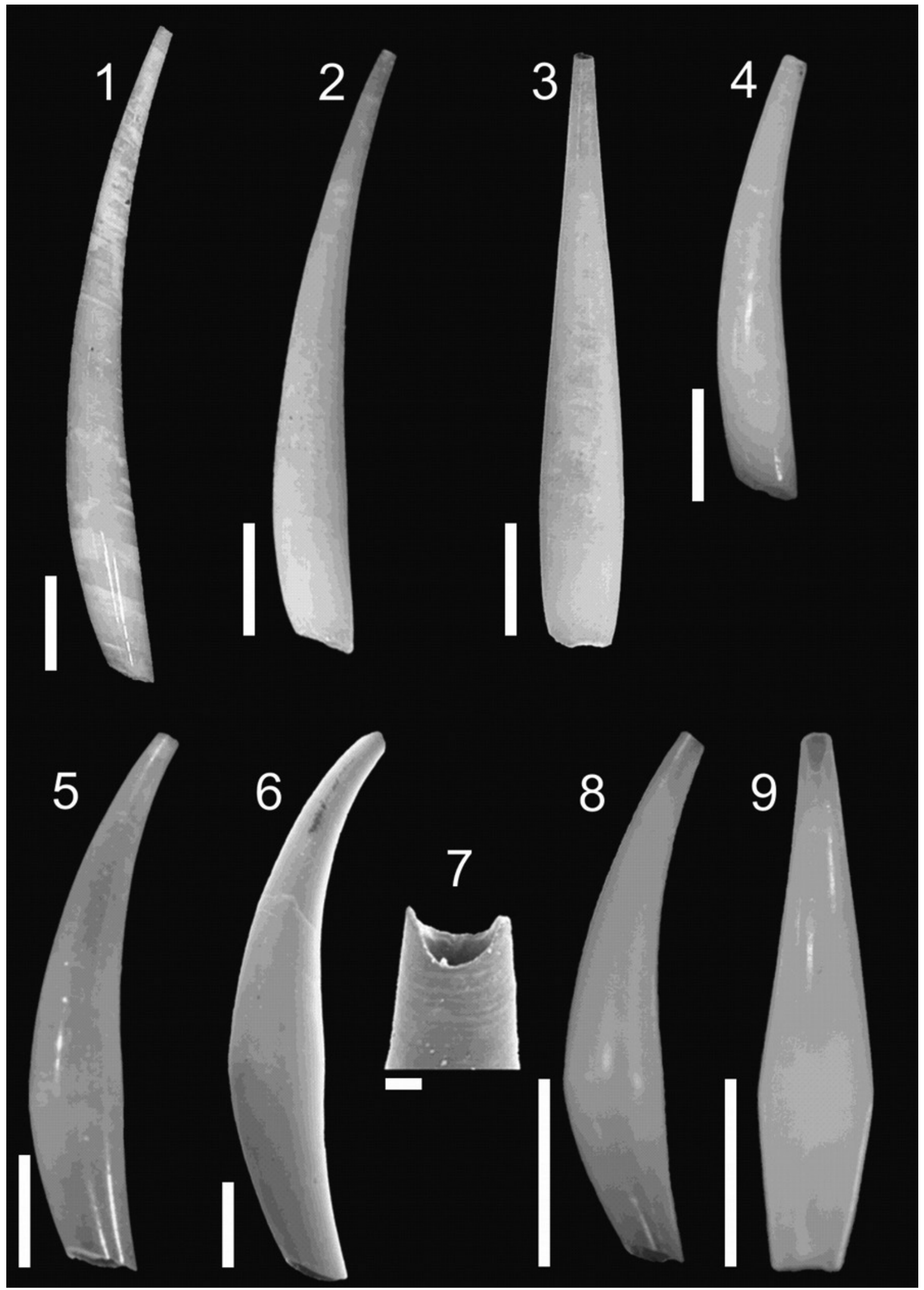

Figure 1. (1-3) Gadila elongata, (1) Holotype USNM 323596, $14.1 \mathrm{~mm}$ length, (2-3) MNRJ 31141, $10.8 \mathrm{~mm}$ length; (4) Gadila longa, Paratype MNRJ 10482, 7.9 mm length; (5-7) Gadila pandionis, (5) Lectotype USNM 38644, $10.0 \mathrm{~mm}$ length, (6-7) IBUFRJ 14314, 13.0 mm length; (8-9) Gadila robusta, Paratype MNRJ 10483, $5.9 \mathrm{~mm}$ length. Scale bars: $(1-6$ and 8-9) $=1.0 \mathrm{~mm} ;(7)=200 \mathrm{~mm}$. 
which led us to doubting whether this taxon existed in Brazilian waters.

The syntypes were examined, but they were in poor conditions. There were two fragments of shell, which appeared to be portions of the anterior and the middle/posterior regions, originated in the same shell or distinct shells. Their bad state made it difficult to recognize conchological features of the species. In this material we observed the presence of primary longitudinal ribs, strongest in the posterior region, and secondary ribs. The original description mentioned the presence of primary ribs, ranging from nine to twelve, as well as secondary ribs. It also showed a notch on the convex surface of the apex and fine lines in the transverse interspaces (Orbigny, 1853: 202), which are not perceptible in the shell fragments of the syntypes examined (BMNH 1854.10.4.467).

Fissidentalium amphialum (Watson, 1879)

Watson (1879) described Fissidentalium amphialum off Rio de La Plata, Uruguay. Lange de Morretes (1949: 54) included this species in her catalogue of molluscs from Brazil, with the remark: "probably occurs in Brazil". Later on, Penna-Neme (1974) reported the occurrence of F. amphialum in Brazilian waters (São Paulo and Rio Grande do Sul). However, re-examining the material studied by Penna-Neme (1974), we concluded that the specimens fit best to the characteristics of Coccodentalium carduus, which occurs in a similar bathymetric range, but reaches large sizes and presents strong and crenulated ribs. While neither the original description nor the illustrations mention the incidence of cross sculpture, except for lines of growth, it is believed that $F$. amphialum should be excluded from Brazilian fauna.

Moreover, according Scarabino (pers. comm.), F. amphialum can be considered a synonym of $F$. candidum. We were able to speculate that Henderson (1920: 59) also shared the same opinion when he mentioned that the original description had indicated similarities with Dentalium meridionale (=Fissidentalium candidum).

Cadulus transitorius Henderson, 1920

Henderson (1920) described two subspecies based on empty shells dredged from the North Atlantic localities. Steiner \& Kabat (2004) stated that their distribution would have been: "Western Atlantic, Caribbean: Bahamas to Brazil". However, these authors did not mention their sources of data from Brazil. Silva-Filho et al. (2012) reported C. transitorius as a new occurrence in Brazilian waters. Here we did not consider this report due to the uncertainties of its description and low resolution of the presented images. In the same way, we revised the publication of Silva-Filho et al. (2012) and observed a series of misidentifications that led us to disregard his work.

\section{Aknowledgments}

The authors express their deepest gratitude to Dr. Alexandre Dias Pimenta (MNRJ), for providing access to the malacological collection, to Dr. Victor Scarabino (Museo Nacional de Historia Natural - Uruguay) for the valuables insights and to Dr. Tito Lotufo (UFC) and two anonymous referees for helpful comments concerning our manuscript. This study was supported by FAPERJ (E-26/111.030/2009).

\section{References}

ABBOTT, R.T. 1974. American Seashells. 2nd ed. Van Nostrand Reinhold Co., New York, London, Melbourne.

ABSALÃO, R.S. 1989. Padrões distributivos e zoogeografia dos moluscos da plataforma continental brasileira. Parte III. Comissão oceanográfica Espírito Santo I. Mem. Inst. Oswaldo Cruz. 84(Supl.IV):1-6.
ADAMS, H. \& ADAMS, A. 1854. The Genera of recent Mollusca; Arranged According to their Organization. v.1. Jan van Voorst, London.

AMARAL, A.C.Z. \& JABLONSKI, S. 2005. Conservation of marine and coastal biodiversity in Brazil. Conserv. Biol. 19(3):625-631. http://dx.doi. org/10.1111/j.1523-1739.2005.00692.x

BAKER, F.C. 1891. Notes on a collection of shells from southern Mexico. P. Acad. Nat. Sci. Phila. 43:45-55.

BOSS, K.J. 1982. Mollusca. In Synopsis and classification of living organisms (S. Parker, ed.). McGraw-Hill, New York.

BUITRAGO, J., CAPELO, J., GUTIÉRREZ, J., RADA M., HERNÁNDEZ, R. \& GRUNE, S. 2006. Living macromolluses from a paleo-reef region on the northeastern Venezuelan continental shelf. Estuar. Coast. Shelf S. 66:634-642. http://dx.doi.org/10.1016/j.ecss.2005.11.006

CABRAL, C.C.G. \& MELLO, R.L.S. 1994. Mollusca Scaphopoda da plataforma continental e da região intertidal da costa leste do Brasil. Ecologia e considerações biogeográficas. Bol. Mus. Malacol. 2:23-56.

CAETANO, C.H.S. \& ABSALÃO, R.S. 2005. A new species of the genus Polyschides Pilsbry \& Sharp, 1898 (Mollusca, Scaphopoda, Gadilidae) from Brazilian waters. Zootaxa. 871:1-10.

CAETANO, C.H.S.; GARCIA, N. \& LODEIRO, C.J.M. 2007. First record of Paradentalium infractum (Odhener, 1931) (Mollusca, Scaphopoda, Dentaliidae) from the east coast of Venezuela. Braz. J. Biol. 67(4):797-798. PMid:18278342. http://dx.doi.org/10.1590/S151969842007000400035

CAETANO, C.H.S \& SANTOS, F.N. 2010. Mollusca, Scaphopoda, Gadilidae, Striocadulus magdalenensis Gracia and Ardila, 2009: First record of the genus and species from Brazil. Check List. 6:587-589.

CAETANO, C.H.S. \& SCARABINO, V. 2009. Class Scaphopoda Bronn, 1862. In Compendium of Brazilian Shells (E.C. Rios, ed.). Evangraf, Rio Grande.

CAETANO, C.H.S, SCARABINO, V. \& ABSALÃO, R.S. 2006. Scaphopoda (Mollusca) from the Brazilian continental shelf and upper slope $\left(13^{\circ}\right.$ to $21^{\circ} \mathrm{S}$ ) with descriptions of two new species of the genus Cadulus Philippi, 1844. Zootaxa. 1267:1-47.

CAETANO, C.H.S., SCARABINO, V. \& ABSALÃO, R.S. 2010. Brazilian species of Gadila (Mollusca: Scaphopoda: Gadilidae): rediscovery of Gadila elongata comb. nov. and shell morphometrics. Zoologia. 27(2):305308. http://dx.doi.org/10.1590/S1984-46702010000200015

CAMP, D.K., LYONS, W.G. \& PERKINS, T. H. 1998. Checklists of Selected Shallow-Water Marine Invertebrates of Florida. Florida Marine Research Institute Technical Report TR-3.

CAREGNATO, F.F.; WIGGERS, F.; TARASCONI, J.C. \& VEITENHEIMERMENDES, I.L. 2009. Taxonomic composition of mollusks collected from the stomach content of Astropecten brasiliensis (Echinodermata: Asteroidea) in Santa Catarina, Brasil. Rev. bras. Biociênc. 7(3):252-259.

CHENU, J.C. 1842-1854. Illustrations conchyliologiques, ou description et figures de toutes les coquilles connues, vivantes et fossiles. Fortin, Masson, Langlois \& Leclercq, Paris.

CHISTIKOV, S.D. 1975. Some problems of scaphopod taxonomy. In Molluscs, their Systematic, Evolution and Significance in Nature (I.M. Likharev, ed.). Akademiia Nauka, Leningrad, p.18-21.

CHISTIKOV, S.D. 1979. Phylogenetic relations of the Scaphopoda. In: Molluscs, main Results of their Study (I.M. Likharev, ed.). Akademiia Nauka, Leningrad, p.20-22.

CHISTIKOV, S.D. 1982. Modern molluscs of the family Entalinidae (Scaphopoda, Gadilida), 1: subfamily Heteroschismoidinae. Zool. Zh. 61(5):671-682.

CONRAD, T.A. 1846. Descriptions of new species of fossil and recent shells and corals. P. Acad. Nat. Sci. Phila. 3(1):19-27.

COTTON, B.C. \& GODFREY, F.K. 1933. South Australian Shells. Part VIII - Scaphopoda. S. Aust. Nat. 14(4):135-150. 
DALL, W.H. 1881. Reports on the results of dredgings under the supervision of Alexander Agassiz, in the gulf of Mexico and in the Caribbean Sea $1877-79$, by the U.S.C.S.S. "Blake", Lieutenant commander G.D. Sigsbee, USN, and commander J.R. Bartlett, USN, commanding. XV. Preliminary report on the Mollusca. Bull. Mus. Comp. Zool. 9:33-144.

DALL, W.H. 1889. Reports on the results of dredgings under the supervision of Alexander Agassiz, in the gulf of Mexico and in the Caribbean Sea $1877-79$, by the U.S.C.S.S. "Blake", Lieutenant commander G.D. Sigsbee, USN, and commander J.R. Bartlett, USN, commanding. XV. Report on the Mollusca. Part II. Gastropoda and Scaphopoda. Bull. Mus. Comp. Zool. 18:1-492.

DÍAZ, J.P. \& PUYANA, M. 1994. Moluscos del Caribe Colombiano. Colciencias y Fundación Natura, Santafe de Bogotá.

EMERSON, W.K. 1952. The scaphopod mollusks collected by the first Johnson-Smithsonian deep-sea expedition. Smith. Miscell. Coll. 117:114.

EMERSON, W.K. 1962. A classification of the scaphopod mollusks. J. Paleontol. 36(3):461-482.

FISCHER, P. 1880-1887. Manual de Conchyliologie et de Paléontologie Conchyliologique. Fasc. 2, Paris.

GARCÍA-VALENCIA, C. \& DÍAZ, J.M. 2000. Moluscos y su taxocenoses en los fondos someros del sector sur de la plataforma continental del Caribe colombiano. Bol. Invest. Mar. Cost. 29:73-80.

GRACIA, A.; ARDILA, N.E.; RACHELLO, P. \& DÍAZ, J.M. 2005. Additions to the Scaphopod Fauna (Mollusca: Scaphopoda) of the Colombian Caribbean. Caribb. J. Sci. 41(2):328-334.

GRACIA, A. \& ARDILA, N.E. 2009. Striocadulus magdalensis, a new deepsea scaphopod (Mollusca, Scaphopoda, Gadilidae) from the Colombian Caribbean. Caribb. J. Sci. 41(2):328-334.

GRAY, J.E. 1847. A list of the genera of recent mollusca, their synonyma and types. P. Zool. Soc. Lond. 15(178):129-219.

GUILDING, L. 1834. Observations on Naticina and Dentalium, two genera of molluscous animals. Trans. Linnean Soc. Lond. 17:29-35. http://dx.doi. org/10.1111/j.1095-8339.1834.tb00016.x

HENDERSON, J.B. 1920. A monograph of the east American scaphopod mollusks. U.S. Nat. Bull. 111:1-177. http://dx.doi.org/10.5479/ si.03629236.111.1

JEFFREYS, J.G. 1877. New and peculiar molluscs of the order Solenoconchia procured in the "Valorous" expedition. Ann. Mag. Nat. Hist. 19:153-158. http://dx.doi.org/10.1080/00222937708682111

LANGE DE MORRETES, F. 1949. Ensaio de catálogo dos moluscos do Brasil. Arq. Mus. Parana. 7:5-216.

LEWIS, J.B. 1965. A preliminary description of some marine benthic communities from Barbados, West Indies. Can. J. Zoolog. 43:1049-1074. http://dx.doi.org/10.1139/z65-108

LINNAEUS, C. 1758. Systema Naturae per Regnatria Naturae, Secundum Classes, Ordines, Denera Species, cum Characteribus, Differentilis, Synonymis, Locis. 10 ed. v.1. Regio Animalis, Stockholm.

LUDBROOK, N.H. 1960. Scaphopoda. In Treatise on Invertebrate Paleontology, Part I (Mollusca 1) (R.C. Moore, ed.). Geological Society of America and University of Kansas Press, New York, p.37-41.

MASSUD-RIBEIRO, R. \& CAETANO, C.H.S. 2006. The use of scaphopods (Mollusca) empty shells by sipunculids and crustacean at Brazilian coast. Biociências 14(1):85-87.

MONTEROSATO T.A. 1872. Notizie intorno alle conchiglie fossili di Monte Pellegrino e Ficarazzi. Ufficio Tipografico di Michele Amenta, Palermo.

ODHNER, N.H. 1931. Die Scaphopoden. Zool. Res. Swed. Antarct. Exped. 1901-1904. 2:1-8.

ORBIGNY, A.C.D. 1853. Mollusques. In: Histoire physique, politique et naturelle de l'Île de Cuba, vol. 2 (R. Sagra, ed.). Bertrand, Paris.

PENNA-NEME, L. 1974. Considerações sobre os Scaphopoda (Mollusca) da costa brasileira, com descrição de uma nova espécie. Pap. Avulsos Zool. 28(6):105-126.
PENNA, L. 1972. Moluscos da Baía da Ilha Grande, Rio de Janeiro, Brasil. I. Scaphopoda (Dentaliidae). Pap. Avulsos Zool. 25(22):229-236.

PHILIPPI, R.A. 1844. Enumeratio molluscorum Siciliae cum viventium tum in tellure tertiaria fossilium, quae in itinere suo observavit. v.2. Eduard Anton, Halle.

PILSBRY, H.A. \& SHARP, B. 1897-1898. Class Scaphopoda. In: Manual of Conchology, structural and systematic, with ilustration of the species. Vol. XVII. (Tryon, G.W. ed.) (1897: p.1-144, pls.1-26; 1898: p.IXXXII, 145-280, pls.27-39).

RAFFUCCI, F.A.G. 2007. Nomenclatura de los organismos acuáticos y marinos de Puerto Rico e Islas Vírgenes. v.2. Moluscos de Puerto Rico e Islas Vírgenes Parte 1. Departmento de Recursos Naturales. www.drna. govierno.pr. (último acesso em 10/02/2011).

REDFERN, C. 2001. Bahamian seashells: a thousand species from Abaco, Bahamas. Bahamianseashells.com, Inc.: Boca Raton.

REHDER, H.A. 1942. Dentalium (Antalis) pilsbryi, new name. The Nautilus. 56(2):69.

REYNOLDS, P.D. 2002. The Scaphopoda. Adv. Mar. Biol. 42:137-236. http:// dx.doi.org/10.1016/S0065-2881(02)42014-7

REYNOLDS, P.D. \& STEINER, G. 2008. Scaphopoda. In Phylogeny and Evolution of the Mollusca (W.F. Ponder \& D.R. Lindberg, eds). University of California Press, Berkeley and Los Angeles, p.143-161. PMid:18809530. http://dx.doi.org/10.1525/california/9780520250925.003.0007

RIOS, E.C. \& BARCELLOS, L.P. 1980. Nuevos hallazgos de moluscos marinos para el archipielago de Abrolhos, Bahia. Comm. Soc. Malacol. Uruguay. 5(39):305-310.

RIOS, E.C. \& OLEIRO, T.A.P. 1968. Estudos malacológicos da costa brasileira. Publ. Inst. Pesqui. Mar. 31:1-27.

ROSENBERG, G. 2009. Malacolog 4.1.1: A Database of Western Atlantic Marine Mollusca. Version 4.1.1. http://www.malacolog.org. (último acesso em 02/09/2012).

SACCO, F. 1896. I molluschi dei terreni terziarii del Piemonte e della Liguria. Boll. Mus. Zool. Anat. Comp. Reale Univ. Torino. 11(267):79-98.

SANDER, F. \& LALLI, C.M. 1982. A comparative study of mollusk communities on the shelf-slope margin of Barbados. The Veliger. 24:308318.

SCARABINO, F. 2003. Lista Sistemática de Los Aplacaphora, Polyplacophora y Scaphopoda de Uruguay. Comm. Soc. Malacol. Uruguay. 8:191-196.

SCARABINO, V. 1973. Scaphopoda del sur del Brasil, Uruguay y Argentina hasta $42^{\circ} \mathrm{S}$. - (Sistematica, Distribucion). In: Anais do V Congresso Latinoamericano de Zoologia. 1:192-203.

SCARABINO, V. 1975. Class Scaphopoda. In Brazilian Marine Mollusks Iconography (E.C. Rios, ed.). Fundação Universidade do Rio Grande: Rio Grande, p.180-186.

SCARABINO, V. 1986. Systematic of Scaphopoda, I. 3 new bathyal and abyssal taxa of Gadilida from Atlantic ocean. Com. Zool. Mus. Montevideo. 161:1-15.

SCARABINO, V. 1994. Class Scaphopoda. In Seashells of Brazil (E.C. Rios, ed.). 2nd ed. Fundação Universidade do Rio Grande: Rio Grande, p.305-310.

SCARABINO, V. 1995. Scaphopoda of the tropical Pacific and Indian waters, with descriptions of 3 new genera and 42 new species. In: Résultats des Campagnes Musorstom, v.14 (P. Bouchet, ed.). Memoir. Mus. Natl. Hist. 167:189-379.

SCARABINO, V. 2008. New species and new records of scaphopods from New Caledonia. In Tropical deep sea benthos, vol. 25 (V. Héros, R.H. Cowie \& P. Bouchet, eds.). Memoir. Mus. Natl. Hist. 196:215-268.

SCARABINO, V. 2012. Compressidens pressum (Sharp \& Pilsbry in Pilsbry \& Sharp, 1897). World Register of Marine Species (WoRMS). http:// www.marinespecies.org/aphia.php? $\mathrm{p}=$ taxdetails\&id=344587 (último acesso em 01/10/2012).

SCARABINO, V. \& CAETANO, C.H.S. 2008. On the genus Heteroschismoides Ludbrook, 1960 (Scaphopoda: Gadilida: Entalinidae), with descriptions of two new species. The Nautilus 122(3):171-177. 
SCARABINO, V. \& SCARABINO, F. 2010. A new genus and thirteen new species of Scaphopoda (Mollusca) from the tropical Pacific Ocean. Zoosystema. 32(3):409-423. http://dx.doi.org/10.5252/z2010n3a3

SCARABINO, V. \& SCARABINO, F. 2011. Ten new bathyal and abyssal species of Scaphopoda from the Atlantic Ocean. The Nautilus 125(3):127136.

SILVA-FILHO, G.F.S.; PINTO, S.L. \& ALVES, M.S. 2010. Two new species of the genus Gadila Gray, 1847 (Mollusca, Scaphopoda, Gadilidae) from brazilian coast. Rev. nordest. Zool. 4(1)48-53.

SILVA-FILHO, G.F.S.; TENÓRIO, D.O.; PINTO, S.L. \& ALVES, M.S. 2012. Mollusca Scaphopoda Bronn, 1862 da Costa Nordeste do Brasil. Trop. Oceanogr. 40 (1):29-103.

SIMONE, L.R.L. 2009. Comparative morphology among representatives of main taxa of Scaphopoda and basal protobranch Bivalvia (Mollusca). Pap. Avulsos Zool. 49(32):405-457.

STAROBOGATOV, Y.I. 1974. Xenoconchias and their bearing on the phylogeny and systematics of some molluscan classes. Paleontolog. J. Am. Geol. Inst. 8:1-13.

STEINER, G. \& KABAT, A.R. 2004. Catalogue of species-group names of recent and fossil Scaphopoda (Mollusca). Zoosystema 26(4):549-726.

STEINER, G. 1991. Observations on the anatomy of the scaphopod mantle, and the description of a new family, the Fustiariidae. Am. Malacol. Bull. 9:1-20.

STEINER, G. 1992. Phylogeny and classification of Scaphopoda. J. Mollus. Stud. 58:385-400. http://dx.doi.org/10.1093/mollus/58.4.385

STEINER, G. 1998. Phylogeny of Scaphopoda (Mollusca) in the light of new anatomical data on the Gadilinidae and some Problematica, and a reply to Reynolds. Zool. Scr. 27(1):73-82. http://dx.doi. org/10.1111/j.1463-6409.1998.tb00429.x
STEINER, G. 1999. A new genus and species of the family Annulidentaliidae (Scaphopoda: Dentaliida) and its systematic implications. J. Mollus. Stud. 65:151-161. http://dx.doi.org/10.1093/mollus/65.2.151

STOLICZKA, F. 1868. The Gastropoda of the cretaceous rocks of southern India. Mem. Geol. Surv. India. 2:1-497.

SUMIDA, P.Y.G. \& PIRES-VANIN, A.M.S. 1997. Benthic associations of the shelfbreak and upper slope off Ubatuba-SP, south-eastern Brazil. Est. Coast. Shelf S. 44:779-784. http://dx.doi.org/10.1006/ecss.1996.0150

TURNER, R.D. 1955. Scaphopods of the Atlantis dredgings in the western Atlantic with a catalogue of the scaphopod types in the Museum of Comparative Zoology. Deep Sea Res. 3:309-320.

VERRIL, A.E. 1880. Notice of the remarkable marine fauna occupying the outer banks off southern coast of New England, n. 3. Am. J. Sci. 20:390403.

VERRIL, A.E. 1882. Notice of the remarkable marine fauna occupying the outer banks off southern coast of New England, n. 4. Am. J. Sci. 23:216225.

VERRILL, A.E. 1885. Third catalogue of Mollusca, recently added to the fauna of the New England coast and the adjacent parts of the Atlantic, consisting mostly of deep-sea species, with notes on other previously recorded. Trans. Conn. Acad. Arts Sci. 6:395-452.

WATSON, R.B. 1879. Mollusca of the Challenger Expedition. Parts 1 and 2, Preliminary report on Solenoconchia. J. Linn. Soc. Lond. 14:506-529. http://dx.doi.org/10.1111/j.1096-3642.1879.tb02447.x

WOLFE, D.A. 2008. Mollusks taken by Beam Trawl in the vicinity of Gray's Reef National Marine Sanctuary on the Continental Shelf off Georgia, Southeastern U.S. NOAA Technical Memorandum NOS NCCOS 88. 